\title{
The Politics of State Creation and National Integration in Nigeria
}

\author{
Okonkwo C. Eze ${ }^{1}$, Alexander Elimian ${ }^{1} \&$ Uchenna G. Chinwuba ${ }^{1}$ \\ ${ }^{1}$ Department of History and Diplomatic Studies, Federal University, Wukari, Nigeria \\ Correspondence: Okonkwo C. Eze, Department of History and Diplomatic Studies, Federal University Wukari, \\ Wukari, Taraba State, Nigeria. Tel: 234-80-3686-7099; 234-80-8182-1149. E-mail: okochriseze@gmail.com
}

Received: December 8, $2014 \quad$ Accepted: December 18, $2014 \quad$ Online Published: February 27, 2015
$\begin{aligned} & \text { doi:10.5539/jpl.v8n1p113 } \\ & \text { URL: http://dx.doi.org/10.5539/jpl.v8n1p113 }\end{aligned}$

\begin{abstract}
Agitations for state creation are almost as old as the Nigerian nation. The more states that are created, the more the problem they are intended to solve persists. Just as the exercises enfeeble the constituent units $v i s-\dot{a}$-vis the federal government so do they detach the units one from the other. The state creation exercises have heightened the indigene-non-indigene phenomenon (statism) which is antithetical to a sense of common nationhood. The federal character principle which is intended to moderate competitions among states over national 'cake' has exacerbated ethnic - rivalries and the indigene-settler syndrome in most of the states. The principle should be replicated in the states to accommodate Nigerians there rather than being discriminated against on the basis of their states of origin. What a contradiction! The thrust of this paper is to investigate how far the state creation in Nigeria has helped in knitting the citizens to achieve a common nationhood. The paper posits that state creation exercises are a bag of mixed grills: although they are supposed to ensure even development, they have remained a source of crisis, alienation and distrust in some states which defeat the national integration project.
\end{abstract}

\section{Introduction}

Nigeria is an amalgam of diverse ethnic nationalities at varying degrees of political development before colonialism. Some of these nationalities were encapsulated in the major empires and kingdoms that dotted the political landscape of the present Nigeria. Others continued to resist annexation by these empires and kingdoms until the advent of colonial rule which amalgamated all into one entity. Trailing the 1914 amalgamation were cries of domination and marginalization by virtually all ethnic groups thereby calling for 'self-determination'. These seemingly ethnic-motivated cries and requests for self-determination were underestimated by the Henry Willink Commission of 1957. A decade later, the Yakubu Gowon regime, owing to the foggy political atmosphere in the country, created twelve states out of the four existing regions. This example was followed by virtually all the military regimes after him probably with intention to curry acceptability by the citizens. The exercises which were considered a panacea for the national integration project have had boomerang effects because they have reinforced the problems they were ab initio set out to solve.

In a historical discourse of this nature, it is important to attempt to clear possible obstacles to a firm grasp of the unfolding analysis by defining the topical terms to be found herein. The operational concepts in this paper are essentially Politics and National Integration. Admittedly, scholars, politicians and commentators have traded minds on a generally acceptable definition of the term 'politics'. Politics as defined by Harold Lasswell is an empirical science that studies the shaping and sharing of power about "who gets what, when and how" (Note 1). This appears to suggest that power is pivotal in determining the allocation of resources to the citizenry. M.I. Okwueze does seem to associate himself with the view of the direction of power being determined by the science of politics. As he puts it, "politics is the science of arranging, determining and influencing allocation of power and resources in the life of a people, an organization, a community, nation and the world at large" (Note 2).

He further contends that "politics, in its broad and dynamic perspectives, can be seen as a process of adjustment and inter-play of power and interest within the public sphere and the affairs of a society be it on a local, national or international levels" (Note 3). It is perhaps in the context of this that the prompting of states creation in Nigeria can be appreciated. In the context of this paper, politics is the struggle of a people for uninhibited access to political power, opportunities to contribute to the issues of governance and equitable distribution of national wealth. 


\section{National Integration}

The concept of nation is a Latin derivation-nasci which connotes to be born or a people of common origin or birth. The term has become increasingly elastic as no one definition enjoys acceptance across space and time. For instance, James S. Coleman opines that a nation has to do with "a large group of people who feel that they form a single and exclusive community destined to be an independent state" (Note 4). In his own discourse, Leopold S. Senghor has defined national integration very aptly. He argues that "a nation groups different ethnic fatherlands together in order to transcend them. Unlike them, it is not a natural determination and therefore an expression of the milieu, but a conscious will to construct or reconstruct..." (Note 5). National integration has also been defined as "process whereby the quality of relations among autonomous social units (kinship groups [ethnic groups], cities...) change in such a way as to erode the autonomy of each and make it a part of a larger aggregate" (Note 6). In this paper, national integration is seen as the process that pulls down all obstacles that encumber and inhibit the march towards virile and indivisible nationhood.

\section{Historicization of State Creation in Nigeria}

Sam C. Ugwu has contended that "the kingdoms or social groups which existed before the advent of colonialism and which later came to be grouped into what is known and called Nigeria today, were free and independent kingdoms or political entities, different in area, language, culture and population under distinct powerful traditional rulers" (Note 7). The 1914 amalgamation exercise which adopted the top-bottom-approach without the content of Nigerians sowed the seeds of dissension arising from fears of marginalization and domination among the citizens. Subsequently colonial policies such as the Indirect Rule System and the creation of only three regions of the North, the East and the West further sparked off the separatist tendencies of some groups. As Ugwu further argues, "the problem of agitation for the creation of more states became more compounded when Nigeria was divided into three unequal regions as provided for in the 1946 Richard's Constitution" (Note 8). This was probably because the regions had not just become the units of the federation but also the concentration of effective political power. Just as the regions wanted some measure of autonomy so did their component units.

E.O.Ojo et al appear to support the above position in their argument. They opined that "by 1953, minorities had become united, determined and vociferous in their demands for separate states in difference for the domination and eventual subjugation by the larger ethnic groups in the country" (Note 9). Probably owing to the tempo and intensity of the agitations both Nnamdi Azikwe and Obafemi Awolowo, leaders of the National Council of Nigerian Citizen (NCNC) and the Action Group (AG), respectively, supported the creation of more states along ethnic lines. For instance, as Michael Crowther has put it "the NCNC supported this movement on the grounds that the only way to create a truly united Nigeria would be to create more states, none of which would be large enough to dominate any of the others" (Note 10).

This proposal was as ambitious as it was dubious for obvious reasons. It is unrealistic based on the number of cultural linguistic groups within the country. Apart from this historical fact, neither Azikiwe nor Awolowo was enthusiastic about carving out new states from his region. Put differently, the support for state movement in each other's region became an issues of practical politics amongst the nationalists. This double standardness and the disintegrative capability of the agitations for the Calabar-Ogoja-River (COR), the Mid West and the Middle Belt States gave rise to the establishment of the Henry Willink Commission. In the words of Charles Alfred et al "the Willink Commission that was established in (sic) $26^{\text {th }}$ September, 1957 to look into the fears of the minorities and the (sic) (to) develop the means of allaying them was headed by Henry Willink, with Gordon Hadow, Philip Mason and J.B. Shearer as members" (Note 11). The minority report of Philip Maosn which sealed the hopes of the minority ethnic groups of having their own states would appear to have been grossly influenced by the intrigues of the nationalists. The report reads among other things:

that hopes of the continued unity of Nigeria and justice for individuals must rest initially on the grounds that none of the three major parties could dominate the other and that any party seeking to get such domination within the present political structure must seek support outside its regional stronghold, and therefore amongst the minority groups of the other regions" (Note 12).

Undoubtedly, this anti-state creation stand was intended to maintain regional cohesion as a step towards national integration. But on other side, it not only frustrated the dreams of the minority ethnic groups but also set the foundation for future violent revolts and riots. Perhaps this is why A.E. Afigbo referred to the Report of the Commission as "an exercise in hypocrisy and ostrich-postrusim" (Note 13).

The steam generated by this frustration was first vented through Nande-Nande meaning Burning by the Tiv in 
the Northern Region where "indeed there was to a great extent a general revulsion against the Fulani conquest or dominance" (Note 14). To the Tiv, this status quo ante was ostensibly irksome as it was a subtle way of subordinating them, like other minority ethnic groups, to the continued Hausa-Fulani hegemonic rule. In this circumstance, what appeared to have held Nigeria together in spite of the separatist agitations of the minority groups was the omnipresence of the colonial officials. All in all, the colonial officials maintained a semblance of unity but did not achieve the national integration. Surprisingly, Nigeria lost the first opportunity to ensure the national integration of both the major and minor ethnic groups.

\section{Change and Continuity in the National Integration Drive}

Soon after Nigeria's independence the competition for the control of political power bequeathed by the colonial officials became more intense between and amongst the three major ethnic-based parties. In the words of Dupe Olatunbosun, "the past Nigerian leaders behaved more as Northerners, as Yorubas (sic), as Igbos (sic), and as Middle Belters than Nigerians. The past leaders laid the foundation of tribal (sic) loyalties and ethnic self-determination in Nigeria" (Note 15). Throughout the First Republic, "the suspicion of the majority ethnic groups by the minorities remained a permanent features of Nigerian federation and its politics" (Note 16). The politics of this phase of Nigeria's march towards nationhood was a continuation of that of the colonial era. Not much effort was made to sustain the integration drive as politics was seen from ethnic periscope.

The creation of the Mid-West out of the Western Region was not necessarily to promote the national integration but as punitive measure against the Awolowo-led AG. The speed with which its creation was supported by the legislative acts of both the Northern and the Eastern Regional parliaments puts this point beyond argument. For instance, in the words of Crowther, "in April 1961 the Federal House of Representatives passed a motion for the creation of a new Mid-West Region to be excised from the non-Yoruba areas of the Western Region and within a year its creation had been approved by the Northern and (the) Eastern Region parliaments" (Note 17). Undoubtedly, the intention was to weaken the power base of the AG while at the same time enhance the political influence and opportunities of the NCNC and NPC in both the Western and the Mid-Western Regions.

The creation of only the Mid West Region in the midst of floods of agitations for states by the minority groups was instrumental to the breaking up of the alliance between the J.S. Takar-led United Middle Belt Congress (UMBC) and the AG (Note 18). The attempts by the leadership of the UMBC to ally with the NPC in the hope of realizing the dream of a Middle Belt State resulted in the political crisis referred to as Atem-tyoh (meaning head breaker) of 1964. Quite undeniably, this crisis, to some extent, accounted for the military coup d'état of January 15,1966 with the attendant disruption of the national integration drive. On the strength of this, carving out of the Mid West region, at the utter neglect of other requests, can hardly go for an integrating effort on the part of the Federal Government.

The July 29, 1966 counter-coup ushered in the Yakubu Gowon regime. In order to assuage the minority ethnic groups and also to break the triangular rivalry between the North, the East and the West, the Gowon - led administration embarked on creating twelve states in Nigeria. According to A. E. Afigbo, "the mood of the time was ugly and the immediate objective in view in creating the states was... largely punitive - to deprive the majority ethnic groups of their exclusive grip on Nigerian politics and affairs" (Note 19). For instance, the lumping of the entire Igbo people, the third largest group, in defunct East Central State would seem to have put them in the rear in the Nigeria's political chessboard. This did not enthrone equity, justice and fair play and therefore constituted a threat to the national integration.

The creation of Rivers State as well as the Nigeria-Biafra civil war introduced the 'Abandoned Property' phenomenon in the Nigerian socio-political parlance. As Paul Obi-Ani has noted "in the two Eastern States of Rivers and Cross River States, Igbo people's attempt to reclaim their properties were(sic) rebuffed at the end of the war" (Note 20). Nothing seemed more disintegrative than this as all the landed property of a section of Nigeria was regarded as being abandoned in the same country. In this circumstance, it can be said that states creation in Nigeria was intended to serve the particularistic interests of some groups thereby segmenting the citizens rather than integrating them. In all fairness, this did not promote an ideology for nationalism needed for virile nationhood.

Since the creation of twelve states in 1967 by the Gowon Administration, it has become more or less a recurring exercise especially among the military regimes. It seems clear that the legitimacy deficit of the military propped them into creating states and local government areas as a way of currying support from the populace. E.C.M. Akamobi has rightly observed that "quite understandably, the exercise is indeed a quintessential political game used by our erstwhile military rulers to play to the gallery and divert the attention of Nigerians on their demand for return to democracy and to allow the military egg-heads to ride on" (Note 21). Prior to the military incursion 
into Nigeria's political space, there existed four regions. Out of these there were created thirty six states with the Federal Capital Territory enjoying the status of a state.

The outcome is that these state creation exercises have tended to produce a 'divided self' in the Nigerian people. As Toyin Falola et al put it "the creation of states in 1967, 1976 and 1987, respectively, produced a rash of traditions, revising old ones concerning the relationship between communities in many parts of the country" (Note 22). In other words, the exercises indirectly turned some Nigerians into 'indigenous aliens' in their fatherland. This is because the historical origins of indigene-settler syndrome can be said to be interwoven with the creation of states. D. Abubakar's argument that state creation exercises have drawn Nigerians "into the primordial public realm of kinship and ethnicity" (Note 23) appears instructive here. It is, therefore, legitimate to state that the creation of states as a panacea to disunity and antidote to cries of exclusion and discrimination appears misplaced as it has exacerbated these problems.

The proponents of state creation seem to have taken a one-sided view of the economic benefits without an ounce of consideration for the opportunity cost to the national integration project. As Emeka Esogbue has noted "creation of more states has brought development economically to the door steps of many towns and citizens, many of which have been labeled, as capital cities or headquarters" (Note 24). The question that begs for an answer is whether every major town must be a state capital before it receives development projects. According to P.T. Vande "the question remains whether the continuous balkanization of Nigeria into smaller, weaker and unviable units has actually brought government or power as well as development closer to the people" (Note 25). This argument would appear to debunk the received notion that state creation brought development nearer to the mass of the people.

The creation of states has rather engendered internal rivalries and conflicts between the major and minor ethnic nationalities within some states over access to state power and resources. This replicates itself at the macro level hence R. Okonkwo has contended that "the division into more states has increased local loyalties and prevented the potential for unity among the larger ethnic groups" (Note 26). On the strength of this, state creation exercises have tended to make the national integration project a tantalizing mirage and elusive. This explains why "since 1963, state creation has not been a basis for resolving the national question and the attendant problems" (Note 27). It is no more than "a means of elite formation, instead of ensuring even development or redressing regional imbalance" (Note 28) and promoting national integration.

There is another aspect of strain and stress caused by state creation exercises on the national integration project. In this direction, there were isolated attempts by some State Governors to de-secularize their states especially in the Northern part of Nigeria where Islamic legal system was introduced. It seems clear that this was a case of one nation, two legal systems; a development that was fraught with crises given the multi-religious composition of Nigeria. As D. Abubakar has perceptively argued that "the continuous introduction of the Sharia legal system by Northern States such as Kano, coupled with its highly cosmopolitan and multi-ethnic as well as multi-religious demography suggests, in a deeper way, the magnitude of the dilemmas of Nigeria's national unity project" (Note 29). This can be said to be disruptive to the national integration drive because, sufficiently, it unsettled the age-long spirit of oneness and understanding.

\section{State Creation and the Indigene-Settler Syndrome}

The creation of states in an environment where "the perception that the indigeneship of a particular society, group or region confers certain rights, which others should not enjoy by virtue of being settlers or migrants or strangers" (Note 30) does not seem to enhance national cohesion. The exercises had in some cases balkanized ethnic groups into many states where such groups were regarded as non-indigenes. The case of the Tiv and the Jukun in Central Nigeria would seem to underline this position. It is significant to note that the Tiv are at present found in Benue, Taraba, Nassarawa and Plateau States. Apart from the Benue, the other three States have tended to treat the Tiv as non-indigenes rather than citizens in spite of the antiquity of their habitation or residence there.

On the other hand, the Jukun are found in Taraba, Benue, Plateau Nassarawa State. In spite of their long residence in these states, the Jukun are still regarded as non-indigenes save in Taraba.

As G.A. Vaaseh has postulated:

The creation of Benue and the then Gongola States in 1976 was a milestone in the Tiv-Jukun relationship as this intensified the conflicts between the two ethnic groups. This is because of the Jukun claim for the ownership of the then Gongola State (and later Taraba), has led to conflicts with the Tiv persistently being asked to relocate to their own state (Note 31 ). 
The attempt at welding a unified nation out of the multiplicity of ethnic groups appears stunted by the state creation exercises as exemplified by the above development.

With the creation of states came the collapse of pan-regional bond especially in the Middle Belt zone. The competition for state power and resources has turned to be conflictual. According to the World Organization Against Torture report "these issues are the key factors in the 2001 Tiv-Alago as well as Tiv-Jukun crisis. In the latter, there is competition for access to resources between those that consider themselves 'indigenes' (the Jukun) and those that are considered as more recent settlers" (Note 32). In the same vein, the unhealthy competition for position and influence, to a great extent, unsettled the centuries-old good neigbourliness between the Hausa-Fulani and the Tarok, the Birom, the Amo, the Anaguta, the Afizere etc in Jos, Plateau State. The creation of Jos South and North Local Government Areas which appeared to have favoured the Hausa-Fulani 'settlers' provided a casus belli for the breakdown of age-long inter- relations that had existed between the 'indigenes' and 'settlers'.

The appointment of Sanusi Mato, a non indigene, as the Chairman of the Jos North Local Government Council (Note 33) fanned the embers of distrust, discontent and malignity into an open conflagration. To the indigenes, the creation of these two Local Government Areas and the appointment of Mato appeared to be a subtle way to short-change and alienate them in their home. Bailey Sale appears to share this view. His words "...the issue of the creation of Jos North and South Local Governments against the wishes of the indigenes created backlash in the hitherto peaceful Plateau State with the first ever religious conflict recorded in 1994, which militarized the society" (Note 34). It seems clear that religion has been turned into a factor of disintegration and disunity rather than a viable tool for coherent national integration. For instance, "since the return to civil rule in May 1999, there have been well over 100 religious and ethnic conflicts resulting in great losses of lives and property, the most recent of which are the series of conflicts that started from Maiduguri on February $18^{\text {th }}$, spreading to many other cities in the country (Potiskum, Kontagora, Enugu, Onitsha, Bauchi, and Katsina)" (Note 35). This identity crisis replicated itself in other parts of Nigeria. As C.O. Obasi has succinctly argued "the conflict among Itsekiri, Ijaw and Urhobo in the Delta region, Zango Kataf in Kaduna State, Tiv/Idoma in Benue State, Modakeke/Ife in Osun State, Umuleri/Aguleri in Anambra State, Shadam in Plateau, and many areas fit in neatly into the permanent strangers' phenomenon in Nigeria" (Note 36). It is, therefore, within the ambit of reason to argue that "...rather than promoting national integration, the reorganizations (creation of states and local government areas) provoked an unprecedented orgy of protests, demonstrations and riots involving tens of fatalities" (Note 37).

Generally, the state and local government are creation exercises have engendered citizenship question contrary to the provisions of the Nigerian Constitution of 1999. The Chapter II, section 15 (2-4) states among other things that the "national integration shall be actively encouraged, whilst discrimination on the ground of place of origin, sex, religion, status, ethnic or linguistic association or ties shall be prohibited" (Note 38). However, state creation exercises, rather than enhance the concept of one nation, one people, have introduced in their wake a disintegrative phenomenon euphemistically called 'statism' or indigene syndrome. In this circumstance, some people are regarded as 'settlers', in spite of the fact that "they might have been born, lived, schooled, worked and paid their taxes in the place for decades, yet they are not recognized as indigenes" (Note 39).

What is, however, more worrisome is the fact that 'statism' is made a determinant of the amount of tuition fees in some states. In an attempt to protect 'ours' from ' theirs', some state actors have tended to charge discriminatory fees for ' indigenes' and ' non-indigenes' in their schools. In some other cases, students of other states were out rightly denied admission in their own country; an opportunity accessed sometimes by non-Nigerians. As Ojo et al have observed,

..The creation of new states and local governments immediately fuel pressures for discrimination against new classes of so-called 'non-indigenes', that is Nigerians resident in states or local governments other than their own. All this makes the creation of new states and localities in Nigeria an extremely divisive and disruptive exercise (Note 40).

As it were, state creation exercises were expected to ignite a kind of consciousness that transcended primordial and parochial loyalties in order to promote the national integration project but quite often they never did.

Furthermore, the Federal Character principle does not seem to help matters in addressing the issues of 'indigenous aliens' or 'native foreigners' in Nigeria. For instance, "in as much as the federal character principle tends to promote equitable representation, it indirectly lays credence to an unvoiced policy of exclusion of non-indigenes of a particular area in the political affairs of such a place on grounds of non-indigeneship" (Note 41). There is no doubt that a principle of this nature does promote "diversity in unity" by building walls rather 
than bridges between the component units. As was to be expected, the principle was incapable of harnessing the diversity in Nigeria to foster unity amongst the citizens and therefore the country. This is premised on the fact that "the unity of Nigeria is the unity of individuals in it. The individuals are bound together by political ties of nationality" (Note 42). To an extent the practice of the federal character principle can be said to betray the much touted aspirations of the founding fathers of these states. Instead of enhancing the spirit of patriotism or nationalism needed for the national integration, it unsettles it.

Understandably, marriage which has been a source of permanent bond as well as national integration was brought under strain and stress by state creation exercises. For instance, during the military regime of Sule Ahman in Enugu State, over 4000 'non-indigenes' of all categories in the state public service were disengaged while a total of 1,481 pensioners from neighbouring states had their pension benefits suspended (Note 43). Other Southeastern States at different points in time embarked on similar indigenization policy which abnegated the spirit of Igboness of the people. What was more, among those disengaged were daughters of Enugu State-Umuada Enugu-married to men from other parts of Nigeria. It was difficult for those of them whose spouses were resident in the State and were employees of one federal establishment or the other to abandon their families in order to secure employment with their 'new home states'. Given this, the exercises can be said to have "wrecked untold hardship on the stability of many marriages" (Note 44).

In the case of the Igbo, state creation exercises have produced a 'divided-self' in them or what E. Ezeani has referred to as "united-divided relationship" (Note 45). Interestingly, the case of Justice Ifeoma Jumbo-Ofo (an Anambra woman by birth but Abia by marriage), who could not be sworn-in to represent Abia State in the Federal Appeal Court, is a pointer to the negative use into which state creation has been put. This is one of the inconsistencies inherent in the application of 'state of origin' clause in terms of appointments in Nigeria. It is worrisome that a woman who, on marriage, has shaded off her maiden name for her husband's is still regarded and treated as non-indigene in her matrimonial state. Such a development would appear to have informed the argument that "as laudable as the policy (state creation) was there was a yawning gap between intent and actual ... benefits of the policy, thus making it counter productive" (Note 46).

On the other hand, marriage, as an institution, has acted as a factor of national integration as it has not just bound together peoples of diverse religious persuasions but also built bridges across ethnic divides. In the South West geopolitical zone, for instance, religion is not known to have hindered marriage as exemplified in the inter-religious marriages contracted by notable Muslim personalities with female Christian faithful. These included Asiwaju Bola Ahmed Tinuba (former Governor of Lagos State) with Oluremi Tinubu, Babatunde Fasola (the Governor of Lagos State) with A. Fasola, Alhaji Sikirulahi Ogundele (former Chairman, Ifo Local Government Council of Ogun State) with O.T. Ogundele, Alhaji Semiu Adesina with (former Chairman of Yewa North Local Government Council and Alhaji O.O. Oyalowo with I.E. Oyalowo (Note 47). In this zone where Muslims are neither fundamentalists nor fanatics, inter-religious marriages were but facts of life. In the same vein, Musa Hassan, (a Muslim Nupe) in Niger State is married to Augustina Ezema (an Igbo Christian of the Assemblies of God faith) who has remained a practising Christian, her marriage to a Muslim notwithstanding. Similarly, Mustapha Zubeiru (former General Manager of Niger State Housing Co-operation), a Muslim is married to an Igbo woman of Catholic faith (Note 48). It is interesting to observe that in the above cases, religion has been a viable integrative tool forgoing religious tolerance and national unity.

It seems clear that where state creation exercises have failed to knit Nigerian citizens together, inter-ethnic marriage has triumphed. Understandingly, marriage bond in Nigeria has often transcended family to encompass villages and/or town. Although within some states there existed rabid competition for and conflict over access to state resources and political power, marriage has tended to douse the tempo and intensity of such situation. The efforts to cobweb individuals in a familial bond through inter-ethnic marriages have entwined Nigerians all the more together irrespective of ethnic differences. The distinctive feature of inter-ethnic marriage is that it cut across various strata of the Nigerian society. Apart from such notable personalities as Ibrahim B. Babangida, T.Y. Danjuma and Gabriel Susmam (the Governor of Bend State) who married from other ethnic groups than theirs, there were also some Nigerians who got integrated into some other communities through marriage. For instance, some Hausa-Fulani and Nupe Muslim traders who settled in Enugu Ezike and Ibagwa Nkwo in Northern Igboland such as Ibrahim Adukwu, Baba Omale, Affa Abubakar etc "were able to integrate themselves into the social milieu of their host communities" (Note 49) through marriage. Given this, it can be said that inter ethnic marriage has engendered enduring unity amongst Nigerians than the state creation exercises.

Itse Sagay appears to subscribe to the view which sees state creation as a panacea for inter-ethnic intolerance. According to him, "there is clearly a need for the Nigerian nationalities to enjoy separate and autonomous existence as states, whilst uniting with each other through a Federal Government exercising some basic power, 
and running some common services" (Note 50). In as much as state creation was plausible for the practice of federalism, it would appear to be a source of bitterness and hostility within some states with ethnic plurality as mentioned earlier. Given the multiplicity and intensity of inter-ethnic intolerance experienced in some states in recent years, it seems certain that state creation exercises have not engendered the unity of the people of Nigeria and therefore national integration.

\section{Conclusion}

Since access to political power translates to wealth and influence, the political class has continued to clamour for state creation without due consideration for its disruptive and disintegrative effects on the nation. State creation exercises have segmented and compartmentalized Nigerians into indigenes and non-indigenes in their own country. It is clear that the more states are created, the more the cries of marginalization and exclusion, and for more states. This is because the creation of state has not been a successful antidote to alienation and domination. The balkanization of Nigeria into 36 states has not only 'de-amalgamated' and disintegrated the country but also reversed her to the pre-1914 situation where virtually every ethnic group was self-governing and independent of the other.

Rather than continual balkanization of the country into minute and unviable units, what was needed then (and even now) was re-investing in governance by the political elite. Good governance can, without doubt, ensure even development, uninhibited access to state power and wealth. Bad governance would rather attenuate the demands for new states as a way and means of accessing the resources of the nation. This is because bad governance has concentrated Nigeria's wealth in a few hands thereby leaving the majority in an unprecedented poverty. At it were, state creation exercises have only carved out colonies for the petty bourgeoisie to engage in unbridled primitive accumulation at the expense of the mass of the people who are supposed to own the states. All these translate to a secondary exclusion of a section from being integrated into the mainstream of political development of their states of domicile or residence.

In some multi-ethnic, the majority ethnic groups have tended to see the states as theirs to the exclusion of the minorities. The policy of appointing at least one federal cabinet member from each of the states of the federation had, more often than not, stunted the drive towards unity of purpose among the citizenry. Democracy, as being practiced in Nigeria, does not proffer answer to this issue. This is because most political parties had always opted for candidates from the major ethnic groups who held promises of harvest of bloc votes. This goes to show that "the basic ethnic orientation of Nigerian politics had defied constitutional and structural reforms carried out by the military to change the character of the polity" (Note 51).

In some other states, religion has had a dominant role to play even in elections. In Nigeria, apart from the African Traditional Religion, the two prominent and mutually antagonistic religions are Christianity and Islam. In the recent years, they have become "a powerful mobilizing force, a medium of cultural representation, and a mode of political engagement" (Note 52). Religion can therefore be said to have provided a vent through which ethnic identity or 'statism' was violently expressed. In other words, most of the ethno-religious crises experienced in Nigeria were no more than attempts at expressing opposition to political exclusion and economic domination in the states. All considered, religion has been employed to short-circuit human rights and freedom of speech of Nigerians especially in the North East Zone where the Boko Haram insurgents have unleashed unwanted and irreparable damages to the national integration drive. The atomization of states has also broken the pan-regional civil service that had hitherto provided integrative mechanism. Civil servants who failed to 'return and develop' their new states after each exercise stood the risk of losing their means of livelihood. This was in spite of the enormity of their contributions to the growth and development of the old states. This development divided the citizens along state line and was therefore antithetical to the national integration project. Undoubtedly, it was in their 'home states' that such returnees were 'aliens'. State creation exercises in Nigeria have disrupted the unity of the citizens of Nigeria and therefore truncated the march towards national integration. What, therefore, the state creation exercises have foisted on the citizens of Nigeria is 'united-divided relationship' rather than oneness.

\section{Notes}

Note 1. Quoted in P.T. Vande, Ethnicity and the Politics of State Creation in Nigeria" in European Scientific Journal, July Edition Vol. 3 No 16, p. 36.

Note 2. M.I. Okwueze, "Effective Political Participation of Nsukka People: Need for a Paradigm Shift" being a paper at a symposium organized by Nsukka Professional Group on the theme- Nsukka 2020: Agenda for Zonal Transformation at Grace Manor Hotel, Nsukka, 7 April, 2012, p.4. 
Note 3. Ibid, p.4.

Note 4. J.S. Coleman, Nigeria: Background to Nationalism, (Berkeley and Los Angeles: University of California Press, 1963) p. 422.

Note 5. Quoted in I. Nzimiro, "Self-Reliance and Nation-Building" in Towards Self-Reliant Development: Pan African Social Science Review, Journal of Department of Sociology, University of Port Harcourt, No 1, October 1984, p. 58.

Note 6. Quoted in J.I. Osagie, "Regional Cooperation and Integration in Africa" in F.I. Omu et al (eds) Themes in International Studies \& Diplomacy, (Benin City: Mindex Publishing, 2002) p. 166.

Note 7. S. C. Ugwu, Federal System: The Nigerian Experience, (Enugu: MaryDan Publishers, 1998) p. 35.

Note 8. Ibid, p. 35.

Note 9. E.O. Ojo et al, The Politics of States, Local Governments' Creation and Nigeria's Search for Geo-Political Balancing" http:/www.the.politics-of-state creation. html p.338.

Note 10. M. Crowther, The Story of Nigeria, (London: Faber and Faber, 1978) p. 242.

Note 11. C. Alfred et al, "War Economy and the Multi-million Dollars' Security Contracts for Ex-Militant Leaders in the Niger Delta Region of Nigeria" in L. Pugalis (ed) Journal of Good Governance and Sustainable Development in Africa, Vol. 2 No 2, May 2014, p. 46.

Note 12. Quoted in Crowther, p. 244.

Note 13. A.E. Afigbo, Federal Character: Its Meaning and History, (Owerri: RADA Publishing Company, 1986) p. 10.

Note 14. L.E. Otoide, "Renegotiating Political Space: Minorities, Border-Disputes and Inter-Communal Clashes" in R.A. Olaniyan (ed) The Amalgamation and Its Enemies: An Interpretive History of Modern Nigeria, (Ile-Ife, OAU Press Ltd, 2003) p. 100.

Note 15. D. Olatunbosun, “Leadership: Nigeria’s Fundamental Problem” in The Guardian, February 19, 2006, p. 56.

Note 16. Afigbo, p.9.

Note 17. Crowther, p. 262.

Note 18. Oral interview with Joseph Jande aged about 80 years at Abako Village of Katsina Ala L.G.A, Benue State on 11 Oct, 2014.

Note 19. Afigbo, p. 10.

Note 20. P.O. Obi-Ani, Post-Civil War Political and Economic Reconstruction of Igboland, 1970-1983, (Nsukka: Great AP Express Publishers Ltd, $2^{\text {nd }}$ Edition, 2009) p. 90.

Note 21. E.C.M. Akamobi, "The Politics of State Creation" http://www.thenigerianvoice.com/nvnews/32437/1/the-politics-of-state-creation.html, pp. 1-2.

Note 22. T. Falola et al, History of Nigeria I: Nigeria Before 1800 AD, (Lagos: Learn Africa Plc, 2012) pp 3-4.

Note 23. D. Abubakar, "The Historical Sociology of the Problem of Nigerian Statehood" in R.A. Olaniyan (ed) The Amalgamation and its Enemies ... p.90.

Note 24. Quoted in Vande, p. 42.

Note 25. Ibid, p. 42.

Note 26. R. Okonkwo, "National Integration in Nigeria" in O. Anichebe (ed) Issues in Nigerian Peoples and Culture, $9^{\text {th }}$ Edition (Nsukka: AFRO-ORBIS Publications Ltd, 2009) p. 34.

Note 27. Vande, p. 44.

Note 28. Ugwu, p. 44.

Note 29. Abubakar, p. 92.

Note 30. I.E. Ibenekwu, "The 1999 Constitution and the Issues of Indigeneship and Citizenship in Nigeria" in S.M. Onuigbo et al (eds) Ikenga: International Journal of Institute of African Studies Vol. 15 Nos 1 \& 2, University of Nigeria, Nsukka, April 2013, p. 156. 
Note 31. G.A. Vaaseh, 'Idigenes' or 'Settlers'? The Geopolitics of the Tiv-Jukun Conflicts, 1976-2003" in T.Wuam et al, (eds) The Military Invasion of Zaki-Biam, (Makurdi: Aboki Publishers, 2013) p.2.

Note 32. Quoted in O. Alubo, "Citizenship and Nation Making in Nigeria: New Challenges and Contestations" in I. Ahmed et al (eds) Identity Culture and Politics: An Afio-Asian Dialogue, Vol. 5 Nos $1 \& 2$ 2004, ICES CODESRIA, p. 143.

Note 33. See O. Alubo, Ethnic Conflicts and Citizenship Crises in Central Nigeria, (Lagos: Eddy Abae Nigerian Press, 2011) p. 18.

Note 34. B. Saleh, Militarization of Ngerian Politics, (Kaduna: Pyla-Mak Services Ltd, 2010) p. 37.

Note 35. Quoted in M. J. Kuna, "Religion, Identity and National Integration in Nigeria"http://www.academia.edu/255519/Religion-Identity and National Integration, P.2

Note 36. C.O. Obasi, Ethnic Conflict and Reconciliation in Nigeria: The Way Forward, (Owerri: Claretian Communications, 2010) p. 55.

Note 37. Quoted in Ojo et al, p. 346.

Note 38. The Constitution of the Federal Republic of Nigeria (Promulgation) 1999 No 25, p. L 26.

Note 39. Obasi, $p .57$.

Note 40. Ojo et al pp 353-4.

Note 41. Ibenekwu, p. 164

Note 42. Quoted in Coleman, p. 339.

Note 43. See M.F.O. Eze, "Government Statement on Indigenization" in Enugu State Military Administrator, Col. Sule Ahman: One Year in Office, (Enugu: Fiac Printers, 1997) pp 14-15 (See also D. Eze, "Enugu State and Her Neighbours" in Enugu State at 6: A Requiem Mass for Dichotomy: A Book of Reading Vol. 1 No 1 (Enugu: Magnet Business Enterprises, 1997) p. 58.

Note 44. Ibenekwu, p. 160.

Note 45. E. Ezeani, In Biafra Africa Died: The Diplomatic Plot, $2^{\text {nd }}$ Edition, (London: Veritas Lumen Publishers, 2013) p. 46.

Note 46. C.A. Onifade, et al, "Towards National Integration in Nigeria: Jumping the Hurdles" in Research on Humanities and Social Science, Vol. 3 No 9 2013. http://www.iiste.org, p.14.

Note 47. Oral interview with O.O. Oyalowo aged about 78 years at Lagos on 15 January, 2015.

Note 48. Oral interview with Fabian Odo aged about 81 years at Nsukka, Enugu State, on 18 January, 2015.

Note 49. O.C. Eze et al, "Trade, Islam, and Politics in Northern Igboland: Ibagwa and Enugu Ezike Experience up to 1970", in Afro Asian Journal of Social Sciences vol. 3, No. 3.1 Quarter 1 2012, www..onlineresearchjournal.com/aajoss/art/81.pdf,p.11.

Note 50. I. Sagay, "Nigeria: Federalism, the Constitution and Resource Control" in Urhobo Historical Society, http://www.waado.org/nigerdelta/essays/resourcescontrol/sagay.html, p.9.

Note 51. J.D. Barkan et al, "State and Local Governance in Nigeria" http://info.worldsank.org/etools/dois/library /5783/State and Gove... August 2, 2001, p.10.

Note 52. Kuna, p.3.

\section{Copyrights}

Copyright for this article is retained by the author(s), with first publication rights granted to the journal.

This is an open-access article distributed under the terms and conditions of the Creative Commons Attribution license (http://creativecommons.org/licenses/by/3.0/). 